\title{
New data on the geographic distribution of chromosome races of Sorex araneus (Soricidae, Eulipotyphla) in European Russia
}

\author{
Natalia V. Bystrakova*, Nikolai A. Shchipanov, Nina S. Bulatova, \\ Boris I. Sheftel, Rena S. Nadjafova, Svetlana V. Pavlova, Tatiana B. Demidova, \\ Anatoly V. Bobretsov, Dmitry Yu. Aleksandrov, Alexei A. Kalinin, \\ Alexander V. Kouptsov, Alfia T. Volkova, Victor Yu. Oleinichenko \\ \& Jeremy B. Searle
}

\begin{abstract}
New information is presented on the distributional ranges of the West Dvina, Moscow, Neroosa, Serov, Sok and Yuryuzan chromosome races in European Russia. Our study provides chromosome data on 67 common shrews from 28 localities in various parts of the East European Plain and foothills of the Ural Mountains. No new chromosome races were discovered but our data added substantially to the known geographic range of the Serov race both north- and southwards from the Asian slopes of the Ural Ridge where it was first described. This race also extends into northern Europe far to the west of the Ural Ridge. The known distribution of the Neroosa race has also been considerably extended. These data allow us to predict locations for contact zones between the following pairs of races: West Dvina - Moscow, Moscow - Neroosa, Sok - Serov.
\end{abstract}

KEY WORDS: common shrew, chromosome race, contact zone, geographic range, Sorex araneus.

NataliaV. Bystrakova [ermakov@penza.com.ru], Penza State Pedagogical University, Penza 440602, Russia; Nikolai A. Shchipanov, Nina S. Bulatova, Boris I. Sheftel, Rena S. Nadjafova, Svetlana V. Pavlova, Tatiana B. Demidova,Dmitry Yu. Aleksandrov, Alexei A. Kalinin, and AlexanderV.Kouptsov[admin@sevin.ru], A.N.Severtsov Institute of Ecology and Evolution, Russian Academy of Sciences, Leninskii pr. 33, Moscow 119071, Russia; Anatoly V. Bobretsov[pechora@komifree.ru], Pechora-Ilych State Nature Reserve, Yaksha, Troitsko-Pechorskii raion 169436, Komi Republic, Russia; Alfia T.Volkova [volkovufa@mail.ru], Bashkir State Pedagogical University, Ufa 450000, Republic Bashkiria, Russia; Victor Yu. Oleinichenko [oleinich@orc.ru], Moscow State University, Faculty of Biology, Moscow 119899, Russia; Jeremy B. Searle [jbs3@york.ac.uk], Department of Biology, University of York, York YO10 5YW, United Kingdom.

\section{Новые данные о географическом распространении хромосомных рас обыкновенной бурозубки (Soricidae, Eulipotyphla) в Европейской России}

\author{
Н.В. Быстракова, Н.А. Щипанов, Н.Ш. Булатова, Б.И. Шефтель, \\ Р.С. Наджафова, С.В. Павлова, Т.Б. Демидова, А.В. Бобрецов, \\ Д.Ю. Александров, А.А. Калинин, А.В. Купцов, А.Т. Волкова, \\ В.Ю. Олейниченко, Дж.Б. Сирл
}

РЕЗЮМЕ. Получены новые данные о распространении хромосомных рас Западная Двина, Москва, Нерусса, Серов, Сок и Юрюзань в Европейской России. Представлены хромосомные характеристики 67 обыкновенных бурозубок из 28 мест в разных частях Восточно-Европейской равнины и предгорий Урала. Новые хромосомные расы не обнаружены, вместе с тем наши данные дополняют существенно сведения об ареале расы Серов, как на юг, так и к северу от азиатского склона Урала, где она была впервые описана (Polyakov et al., 2000). Показано распространение этой расы на европейском севере России далеко к западу от Уральских гор. Ареал расы Нерусса также значительно расширен. Новые данные по хромосомным российским расам обыкновенной бурозубки позволяют предсказывать расположение межрасовых зон контакта. Намечены, в частности, зоны контакта между следующими парами рас: Западная Двина - Москва, Москва - Нерусса, Сок - Серов.

КЛЮЧЕВЫЕ СЛОВА: обыкновенная бурозубка, хромосомные расы, зоны контакта, географическое распространение, Sorex araneus. 


\section{Introduction}

The most recent list of chromosome races of the common shrew Sorex araneus includes 13 races from European Russia (Wójcik et al., 2003), the majority of which were discovered in the last 10 years or so (Orlov et al., 1996; Bulatova et al., 2000; Kozlovsky et al., 2000; Bystrakova et al., 2003). Now the focus is shifting to a search for the contacts between these races (Bystrakova et al., 2003). The first description of a hybrid zone in European Russia is given in this volume (Bulatova et al., 2007). Here we report distribution data on six previously described chromosome races and use these data to suggest locations for new contact zones. Some of these data were reported previously in Shchipanov et al. (2005) and Bystrakova et al. (2005), but this is the first time that any of this material has been presented in English.

\section{Material and methods}

Shrews were collected for chromosome studies during the field seasons of 2003-2005. Conventional preparations were obtained from bone marrow and spleen cell suspensions of colchicinized animals. A standard trypsin G-banding technique was applied and the chromosome races were defined according to the rules of the International Sorex araneus Cytogenetics Committee, ISACC (Searle et al., 1991).

\section{Results and discussion}

Tab. 1 and Fig. 1 present new chromosome data and we interpret these data on a race-by-race basis.

Moscow race. In addition to 11 localities previously reviewed in Bulatova et al. (2000), the typical karyotype of the Moscow race with five stable diagnostic

Table 1. Karyotype and location data for 67 common shrews from 28 localities in nine regions of European Russia (only diagnostic chromosomes indicated).

\begin{tabular}{|c|c|c|c|c|c|c|}
\hline Region: Site & Coordinates & $\begin{array}{l}\text { Number of } \\
\text { specimens }\end{array}$ & $2 \mathrm{NA}$ & Karyotype & Race & Ref. \\
\hline \multicolumn{7}{|l|}{ Tver Province } \\
\hline Toropets & $\mathrm{N} 56^{\circ} 45^{\prime}$, E $31^{\circ} 30^{\prime}$ & 2 & 18 & $g m, h k, i p, n o, q r$ & West Dvina & 1 \\
\hline Konakovo & $\mathrm{N} 56^{\circ} 44^{\prime}$, E $36^{\circ} 33^{\prime}$ & 4 & 18 & $g m, h i, k r, n o, p q$ & Moscow & 1 \\
\hline \multicolumn{7}{|l|}{ Moscow Province } \\
\hline Antsiferovo & $\mathrm{N} 55^{\circ} 35^{\prime}$, E $38^{\circ} 46^{\prime}$ & 2 & 18 & $g m, h i, k r, n o, p q$ & Moscow & 1 \\
\hline Ryazanovsky & $\mathrm{N} 55^{\circ} 09^{\prime}$, E $39^{\circ} 30^{\prime}$ & 4 & 18 & $g m, h i, k r, n o, p q$ & Moscow & 1 \\
\hline \multicolumn{7}{|l|}{ Ryazan Province } \\
\hline Rybnoye & $\mathrm{N} 54^{\circ} 47^{\prime}$, E $39^{\circ} 21^{\prime}$ & 2 & 18 & $g o, h i, k r, m n, p q$ & Neroosa & 1 \\
\hline Starojilovo & $\mathrm{N} 54^{\circ} 12^{\prime}$, E $39^{\circ} 55^{\prime}$ & 4 & 18 & $g o, h i, k r, m n, p q$ & Neroosa & 1 \\
\hline Ryazan & $\mathrm{N} 54^{\circ} 33^{\prime}$, E $40^{\circ} 08^{\prime}$ & 1 & 18 & $g o, h i, k r, m n, p q$ & Neroosa & 1 \\
\hline Spassk & N 54 ${ }^{\circ} 39^{\prime}$, E $40^{\circ} 45^{\prime}$ & 11 & 18 & $g o, h i, k r, m n, p q$ & Neroosa & 1 \\
\hline Shilovo & 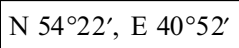 & 7 & 18 & $g o, h i, k r, m n, p q$ & Neroosa & 1 \\
\hline Putyatino & $\mathrm{N} 54^{\circ} 05^{\prime}$, E $41^{\circ} 24^{\prime}$ & 3 & 18 & $g o, h i, k r, m n, p q$ & Neroosa & 1 \\
\hline \multicolumn{7}{|l|}{ Voronezh Province } \\
\hline Lisky & $\mathrm{N} 51^{\circ} 00^{\prime}$, E $39^{\circ} 18^{\prime}$ & 2 & 18 & $g o, h i, k r, m n, p q$ & Neroosa & 2 \\
\hline Pavlovsk & $\mathrm{N} 50^{\circ} 29^{\prime}$, E $40^{\circ} 02^{\prime}$ & 1 & 18 & $g o, h i, k r, m n, p q$ & Neroosa & 2 \\
\hline \multicolumn{7}{|l|}{ Rostov Province } \\
\hline Belaya Kalitva & $\mathrm{N} 48^{\circ} 20^{\prime}$, E $40^{\circ} 51^{\prime}$ & 1 & 18 & $g o, h i, k r, m n, p q$ & Neroosa & 1 \\
\hline \multicolumn{7}{|l|}{ Volgograd Province } \\
\hline Kletskiy & $\mathrm{N} 49^{\circ} 06^{\prime}$, E $42^{\circ} 30^{\prime}$ & 1 & 18 & $g o, h i, k r, m n, p q$ & Neroosa & 1 \\
\hline \multicolumn{7}{|l|}{ Orenburg Province } \\
\hline Kvarkeno & $\mathrm{N} 52^{\circ} 10^{\prime}$, E $60^{\circ} 01^{\prime}$ & 1 & 18 & $g o, h n, i p, k m, q r$ & Serov & 1 \\
\hline \multicolumn{7}{|l|}{ Bashkiria Republic } \\
\hline Beloretsk, Southern Ural Nature Reserve & N $54^{\circ} 11^{\prime}$, E $57^{\circ} 37^{\prime}$ & 1 & $19(\mathrm{j} / \mathrm{l})$ & $g o, h n, i p, k r, m q$ & Yuryuzan & $1 *$ \\
\hline \multicolumn{7}{|l|}{ Komi Republic } \\
\hline River Roptcha & $\mathrm{N} 63^{\circ} 00^{\prime}$, E $52^{\circ} 19^{\prime}$ & 3 & 18 & $g o, h n, i p, k q, m r$ & Sok & 1 \\
\hline
\end{tabular}


Table 1 (continued).

\begin{tabular}{|c|c|c|c|c|c|c|}
\hline Region: Site & Coordinates & $\begin{array}{l}\text { Number of } \\
\text { specimens }\end{array}$ & $2 \mathrm{NA}$ & Karyotype & Race & Ref. \\
\hline \multicolumn{7}{|l|}{ Komi Republic } \\
\hline Ust-Nem vic. & $\mathrm{N} 61^{\circ} 40^{\prime}$, E $54^{\circ} 53^{\prime}$ & 1 & 18 & $g o, h n, i p, k q, m r$ & Sok & 1 \\
\hline Nem River (Vychegda River basin) & $\mathrm{N} 61^{\circ} 40^{\prime}$, E $56^{\circ} 14^{\prime}$ & 2 & 18 & $g o, h n, i p, k m, q r$ & Serov & 3 \\
\hline Ukhta vic. & $\mathrm{N} 63^{\circ} 14^{\prime}$, E $54^{\circ} 21^{\prime}$ & 2 & 18 & $g o, h n, i p, k m, q r$ & Serov & 3 \\
\hline Berezovka River (Kama River basin) & $\mathrm{N} 61^{\circ} 41^{\prime}$, E $56^{\circ} 31^{\prime}$ & 2 & 18 & $g o, h n, i p, k m, q r$ & Serov & 3 \\
\hline Volosnitsa River (Pechora River basin) & $\mathrm{N} 61^{\circ} 42^{\prime}$, E $56^{\circ} 44^{\prime}$ & 1 & 18 & $g o, h n, i p, k m, q r$ & Serov & 3 \\
\hline Pechora River, Yaksha vic. & $\mathrm{N} 61^{\circ} 49^{\prime}$, E $56^{\circ} 50^{\prime}$ & 1 & 18 & $g o, h n, i p, k m, q r$ & Serov & 3 \\
\hline Foothills, Pechora River & $\mathrm{N} 62^{\circ} 03^{\prime}$, E $58^{\circ} 25^{\prime}$ & 4 & 18 & $g o, h n, i p, k m, q r$ & Serov & 3 \\
\hline Ural Mts. (Pechora) & $\mathrm{N} 62^{\circ} 05^{\prime}$, E $59^{\circ} 05^{\prime}$ & 1 & 18 & $g o, h n, i p, k m, q r$ & Serov & 3 \\
\hline Foothills, Ilych River & $\mathrm{N} 63^{\circ} 03^{\prime}$, E $58^{\circ} 36^{\prime}$ & 1 & 18 & $g o, h n, i p, k m, q r$ & Serov & 3 \\
\hline Foothills, Ilych River & $\mathrm{N} 62^{\circ} 38^{\prime}$, E $58^{\circ} 55^{\prime}$ & 1 & 18 & $g o, h n, i p, k m, q r$ & Serov & 3 \\
\hline Foothills, Ilych River & $\mathrm{N} 62^{\circ} 28^{\prime}$, E $58^{\circ} 58^{\prime}$ & 1 & 18 & $g o, h n, i p, k m, q r$ & Serov & 3 \\
\hline
\end{tabular}

References: 1 - present study; 2 - Bystrakova et al., 2005; 3 - Shchipanov et al., 2005; * — data corrected from that published in Zima et al. (1996).

metacentrics ( $g m, h i, k r, n o, p q)$ was detected in three new localities. These findings clarify the boundaries of the Moscow race (\#7 in Fig. 1) along the Upper Volga and its right tributary the Oka and show, first, that it crosses the Volga to the north of the type locality, and second, that it occurs further to the south-east than described previously, where it comes very close to the Neroosa race (\#6). While the contact between the Moscow and Neroosa races is unconfirmed, samples of the Moscow race to the north-west of its range have helped to define a hybrid zone between the Moscow and Seliger races (Bulatova et al., 2007).

West Dvina race. This race with characteristic metacentrics $g m, h k$, ip, no, $q r$ was previously described from only one locality (Bulatova et al., 2002). Now we have found it in a new locality further north in the same Tver region (Tab. 1). These two localities are on opposite banks of the upper reaches of the West Dvina River in the Valdai Heights. It is notable that this race (\#14 in Fig. 1) was found close to where the Moscow and Seliger races form a hybrid zone (near the type locality of the Seliger race \#8; see Bulatova et al., 2007). Thus, it is likely that the Moscow race (\#7) forms a continuous hybrid zone with two other races, the West Dvina (\#14) and the Seliger (\#8), along its western edge.

Neroosa race. Here we describe 10 new localities of the Neroosa race (\#6 in Fig. 1), all characterised by the fully metacentric complement $g o, h i, k r, m n, p q$. We can now say with more confidence that this race forms the southern species boundary in the vicinity of the Lower Don at latitudes below $50^{\circ} \mathrm{N}$. Our new findings in this southern area also extend the known range of the race eastwards to $42^{\circ} 30^{\prime} \mathrm{E}$ (Tab. 1; Fig. 1).

Additionally, we have clarified the distribution of the Neroosa race to the north. In the middle reaches of the Oka River (around longitude $40^{\circ} \mathrm{E}$ ), the Moscow
(\#7) and Neroosa (\#6) races occur close to each other on the left bank of the river. They are separated by 50 $\mathrm{km}$ of marshland. Elsewhere, the Oka River appears to form the boundary between the Neroosa and Moscow races. Further studies are needed to determine whether there is a contact between the Neroosa race and the Mologa race ( $\# 9$; $g m, h n, i o, k r, p q)$, to the north-east (N 56 $20^{\prime}, \mathrm{E} 41^{\circ} 25^{\prime}$ - see Bulatova et al., 2000).

Sok race. Two new findings reported here (Tab. 1) extend the known distribution of this race ( $g o, h n$, ip, $k q, m r)$ further to the north with latitudes $61^{\circ} 40^{\prime} \mathrm{N}$ and $63^{\circ} 00^{\prime} \mathrm{N}$ in the very east of Europe (\#11 in Fig. 1), close to the Serov race (\#12).

Serov race. We provide substantial new data on the Serov race ( $g o, h n, i p, k m, q r)$. This race was first described on the Asian side of the Ural Ridge (Polyakov et al., 2000) and we have now shown that it also occurs on the European side. We have also extended the known range of the race both to the north and the south. The Serov race is found near the southern species boundary in the Orenburg region, close to Kazakhstan (\#12 in Fig. 1).

In total, findings of the latter two races, Sok (\#11) and Serov (\#12), reveal large ranges alongside the Ural Ridge extending from arctic conditions in the north down to desert conditions in the south. The Yuryuzan race (\#10) appears to separate the two races in the south (Fig. 1). As is also clear from Fig. 1, there is very likely a hybrid zone between the Sok and Serov races in the north.

Yuryuzan race. An interesting finding relating to this race is the revision of the previously-described Bashkiria race (XX/XY $\mathrm{Y}_{2}, a f, b c, g m, h o, i n, j / l, k p, q r$, $t u)$ as the Yuryuzan race. The Bashkiria race was listed provisionally with other common shrew chromosome races by Zima et al. (1996, with reference to Gabitova, 


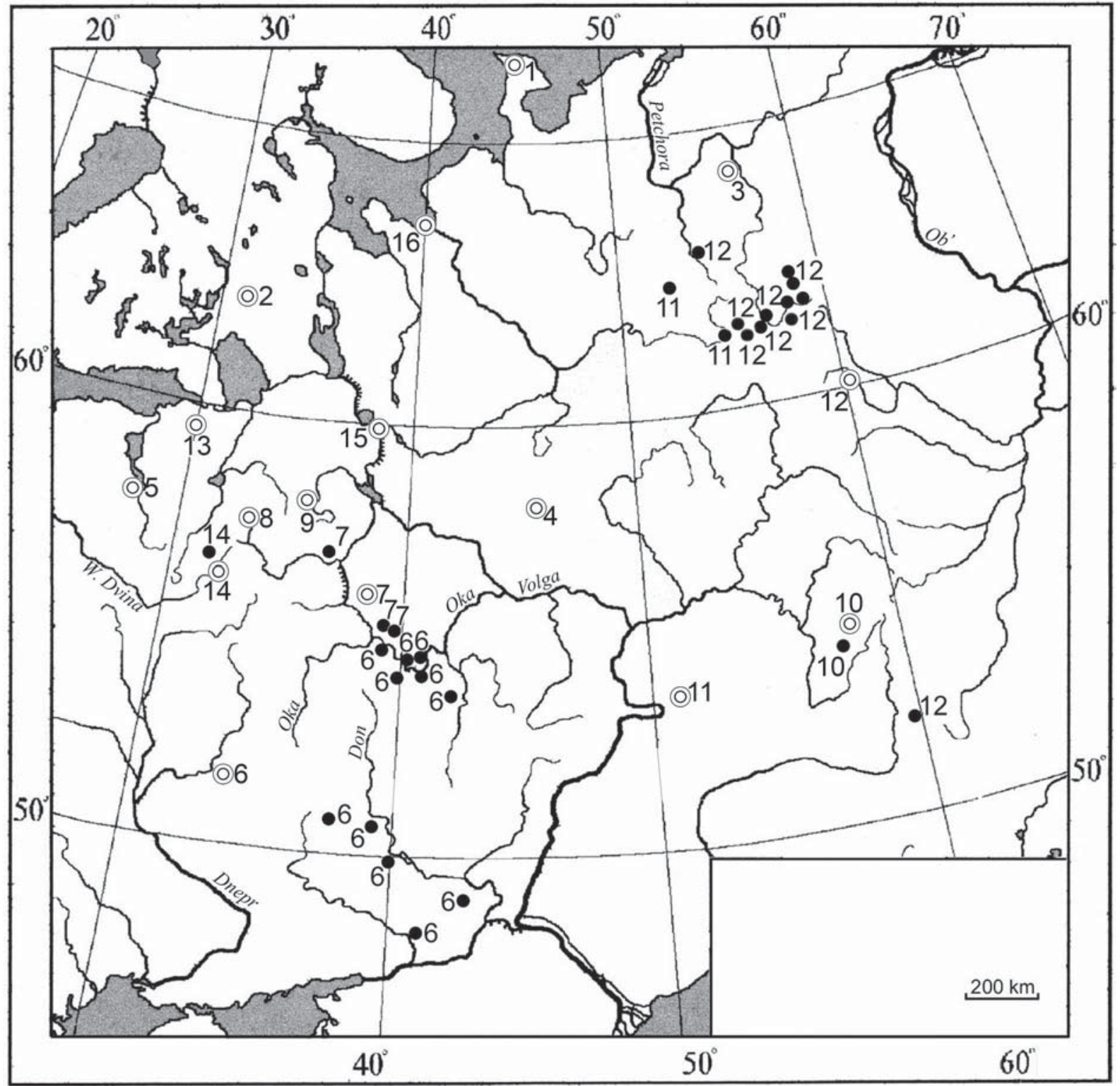

Figure 1. Map showing sampling localities for all 28 new samples from European Russia (black dots) and their racial designation (numbers). The type localities of all chromosome races known in the area are indicated (double circles) based on published sources (Bulatova et al. 2000, 2002; Polyakov et al., 2000; Bystrakova et al., 2005; Shchipanov et al., 2005; Orlov et al., 2007): 1 - Kanin, 2 - Ilomantsi, 3 - Pechora, 4 - Manturovo, 5 - Pskov, 6 - Neroosa, 7 - Moscow, 8 - Seliger, 9 - Mologa, 10 - Yuryuzan, 11 - Sok, 12 - Serov, 13 - St. Petersburg, 14 - West Dvina, 15 - Kirillov, 16 - Yagry.

1992 therein) but then removed from the most recent listing (Wójcik et al., 2003) as not proved because of the absence of a G-band karyotype. A single G-band spread from an individual originally described as the Bashkiria race was presented by Alfia Volkova (formerly Gabitova) at the Eighth meeting of the National Theriological Society held in Moscow, 31 January - 2 February 2007. The clarity of the G-banding allowed Nina Bulatova to identify the specimen as a member of the Yuryuzan race, fully metacentric ( $g o, h n, i p, k r, m q)$ except for heterozygosity for $j l$, the only polymorphism that we observed in this study (Tab. 1).
In conclusion, our new data extend the known ranges of six races in European Russia. Additionally, we have localised likely contact areas between the West Dvina and Moscow races, the Moscow and Neroosa races and the Sok and Serov races. Interestingly, in the areas where we have best identified contact of these races there are no geographic barriers (e.g. rivers, mountain ridges) separating them.

ACKNOWLEDGMENTS. The study was supported by INTAS grant 03-51-4030. 


\section{References}

Bulatova N., Nadjafova R. \& Krapivko T. 2002. Intraspecific phylogenetic relationships in Sorex araneus L.: the southern Baltic subgroup of chromosome races // Russian Journal of Genetics. Vol.38. P.64-69.

Bulatova N., Searle J.B., Bystrakova N., Nadjafova R., Shchipanov N. \& Orlov V. 2000. The diversity of chromosome races in Sorex araneus from European Russia // Acta Theriologica. Vol.45. Suppl.1. P.33-46.

Bulatova N., Shchipanov N. \& Searle J.B. 2007. The Seliger - Moscow hybrid zone between chromosome races of common shrews - an initial description // Russian Journal of Theriology. Vol.6. P.111-116.

Bystrakova N., Bulatova N., Kovalskaya Y., Shchipanov N., Kalinin A., Nadjafova R. \& Searle J.B. 2003. Geographical limits of chromosome races of the common shrew Sorex araneus L. in the Middle Volga (East European Russia) // Mammalia. Vol.67. P.187-191.

Bystrakova N., Ermakov O. \& Titov S. 2005. [Routes for chromosomes on Middle Don] // Informatsionnnyi Vestnik VOGiS. Vol.9. P.67-69 [in Russian].

Kozlovsky A., Orlov V., Okulova N., Kovalskaya Y. \& Searle J.B. 2000. Chromosome studies on common shrews from northern and central parts of European Russia // Acta Theriologica. Vol.45. Suppl.1. P.27-31.

Orlov V., Bulatova N., Kozlovsky A., Nadjafova R. \& Searle J.B. 1996. Karyotypic variation of the common shrew (Sorex araneus) in European Russia: preliminary results
// Hereditas. Vol.125. P.117-121.

Orlov V.N., Kozlovsky A.I., Okulova N.M. \& Balakirev A.E. 2007. Postglacial recolonization of European Russia by the common shrew Sorex araneus // Russian Journal of Theriology. Vol.6. P.97-104.

Polyakov A.V., Zima J., Searle J.B., Borodin P.M. \& Ladygina T. 2000. Chromosome races of the common shrew Sorex araneus in the Ural Mts: a link between Siberia and Scandinavia? // Acta Theriologica. Vol.45. Suppl.1. P.19-26.

Searle J.B., Fedyk S., Fredga K., Hausser J. \& Volobouev V.T. 1991. Nomenclature for the chromosomes of the common shrew (Sorex araneus) // Mémoires de la Société Vaudoise des Sciences Naturelles. Vol.19. P.13-22.

Shchipanov N., Bobretsov A., Bulatova N., Kalinin A., Kuprijanova I. 2005. [Ural chromosome race Serov of the common shrew (Sorex araneus L.: Insectivora, Mammalia) in the polydominant dark-needles taiga in the north of European Russia] // Doklady Akademii Nauk. Vol.404. P.281-285 [in Russian]

Wójcik J.M., Borodin P.M., Fedyk S., Fredga K., Hausser J., Mishta A., Orlov V.N., Searle J.B., Volobouev V.T. \& Zima J. 2003. The list of chromosome races of the common shrew Sorex araneus (updated 2002) // Mammalia. Vol.67. P.169-178.

Zima J., Fedyk S., Fredga K., Hausser J., Mishta A., Searle J.B., Volobouev V.T. \& Wójcik J.M. 1996. The list of the chromosome races of the common shrew (Sorex araneus) // Hereditas. Vol.125. P.97-107. 